\title{
Diversity and aspects of the ecology of social wasps (Vespidae, Polistinae) in Central Amazonian "terra firme" forest
}

\author{
Alexandre Somavilla ${ }^{1}$, Marcio Luiz de Oliveira² \& Orlando Tobias Silveira ${ }^{3}$
}

\author{
'Programa de Pós-Graduação em Entomologia, Instituto Nacional de Pesquisas da Amazônia. alexandre.s@hotmail.com \\ ${ }^{2}$ Coordenação de Biodiversidade, Instituto Nacional de Pesquisas da Amazônia, Av. André Araújo, 2936, 69060-001 Manaus-AM, Brazil. \\ mlolivei@inpa.gov.br \\ ${ }^{3}$ Coordenação de Zoologia, Museu Paraense Emílio Goeldi, Av. Perimetral s/n, Campus de Pesquisas, 66040-170 Belém-PA, Brazil. \\ orlando@museu-goeldi.br
}

\begin{abstract}
Diversity and aspects of the ecology of social wasps (Vespidae, Polistinae) in Central Amazonian "terra firme" forest. The knowledge of social wasp richness and biology in the Amazonian region is considered insufficient. Although the Amazonas state is the largest in the region, until now only two brief surveys were conducted there. Considering that the systematic inventory of an area is the first step towards its conservation and wise use, this study presents faunal data on social wasp diversity in a $25 \mathrm{~km}^{2}$ area of "terra firme" (upland forest) at the Ducke Reserve, Manaus, Amazonas, Brazil. Wasps were collected in the understory, following a protocol of three collectors walking along 60 trails $1,000 \mathrm{~m}$ in extension for 16 days between August and October 2010. Methods used were active search of individuals with entomological nets and nest collecting. Fiftyeight species of social wasps, allocated in 13 genera, were recorded; $67 \%$ of the collected species belong to Polybia, Agelaia and Mischocyttarus; other genera were represented by only four species or less. The most frequent species in active searches were Agelaia fulvofasciata (DeGeer, 1773), Agelaia testacea (Fabricius, 1804) and Angiopolybia pallens (Lepeletier, 1836). Twelve species were collected in nests. Prior to this study, 65 Polistinae species were deposited at the INPA Collection. Collecting in the study grid, an area not previously sampled for wasps, resulted in an increase of $25 \%$ species, and species richness was 86 . According to the results, there is evidence that the diversity of social wasps at the Ducke Reserve is even higher, making it one of the richest areas in the Brazilian Amazonia.
\end{abstract}

KEYWORDS. Active search; Ducke Reserve; Insecta; PPBio; structured inventory.

Vespidae is a family of insects commonly designated wasps that includes over 4,600 valid species worldwide and is found in more abundance in the tropical region, despite the wide distribution of some species (Carpenter \& Marques 2001). Brazilian social wasps include only Polistinae, the richest in the world, with 319 species (Carpenter \& Marques 2001). Species in this subfamily belong to three tribes: Mischocyttarini (Mischocyttarus, with 117 species), Polistini (Polistes, with 38 species), and Epiponini (20 genera, 164 species) (Carpenter 2004).

The number of faunal inventories of social wasps in Brazil can still be considered low. There are some studies on the diversity and density of social wasps in different regions and biomes in Brazil, such as in agroecosystems and anthropogenic environments in the southeast and northeast (e.g., Lima et al. 2000; Auad et al. 2010), in the savanna (cerrado) in the southeast, midwest and northeast (e.g., Lima et al. 2010; Tanaka-Jr. \& Noll 2011; Silva et al. 2011; Grandinete \& Noll 2013), in rocky fields in the southeast and northeast (e.g., Silva-Pereira \& Santos 2006; Prezoto \& Clemente 2010), in the "Pantanal" biome (Almeida et al. 2014) and several environments in the Atlantic rainforest in the southeast and south (e.g. Gomes \& Noll 2009; Somavilla et al. 2010; Tanaka-Jr \& Noll 2011; Locher et al. 2014; Togni et al. 2014).
For the Brazilian Amazonian rainforest, we highlight the work of Raw (1998), Silveira (2002), Silveira et al. (2005), Morato et al. (2008), Silveira et al. (2008) and Silva \& Silveira (2009). For the Amazonas state, Silveira et al. (2008) collected social wasps in the adjoining "várzea" (seasonally flooded forest) in Mamirauá and areas of "terra firme" (upland forest) in Alvarães through active search for wasps and colonies and Malaise trapping, and recorded 46 and 42 species, respectively. Until now, the two sites received the greatest collection effort in the state. However, lack of standardization among the methodologies employed in these studies hampers the comparison of aspects like composition, distribution, and abundance of the social wasp faunas of these regions.

The pioneer in the use of a standardized and replicable wasp collecting methodology in the Amazon Region was Silveira (2002). This author studied the social wasps of the Caxiuanã National Forest, Pará state, using a simple sampling protocol based mainly on the search for individuals and colonies along $1,000 \mathrm{~m}$ long trails and the installation of ten Malaise traps for 60 sampling days; 79 species were recorded. In 2006, working in the same area, Silva \& Silveira (2009) identified 65 species of social wasps using a collection protocol consisting in active search of individuals and 
colonies and the use of ten Malaise traps in a $5 \times 5 \mathrm{~km}$ grid pertaining to the Biodiversity Research Program (PPBio) for 44 days. The advantage of using this grid is that it allows the adoption of more standardized and comparable protocols, making it possible to obtain indirect estimates of relative abundance of most species and the construction of accumulation curves, useful to assess the efficiency of the collection methods applied in inventories.

Considering that the inventory of an area is the first step towards its conservation and wise use, this paper presents data on social wasp diversity in the understory of a $25 \mathrm{~km}^{2}$ grid of PPBio, located at the Ducke Reserve, Manaus, Amazonas, Brazil.

\section{MATERIAL AND METHODS}

Study area. Sampling was conducted at the Ducke Reserve ("Reserva Florestal Adolpho Ducke"), comprising an area of approximately $100 \mathrm{~km}^{2}$ of "terra firme" rainforest near Manaus, Amazonas, Brazil $\left(02^{\circ} 55^{\prime}\right.$ to $03^{\circ} 01^{\prime}$ 'S and $59^{\circ} 53^{\prime}$ to $59^{\circ} 59.5^{\prime} \mathrm{W}$ ) (Baccaro et al. 2008). The climate is classified as humid tropical, with mean annual relative humidity of about $80 \%$ and mean annual precipitation of $1,750-2,500 \mathrm{~mm}$, the rainiest months falling between November and May (Ribeiro \& Adis 1984). Mean annual temperature is $26^{\circ} \mathrm{C}$, with little variation during the year (Marques-Filho et al. 1981). The land is dominated by plateaus with altitudes ranging from 80 to $140 \mathrm{~m}$ (Pires 1974). Soils are clayey in plateaus; in slopes, the clay fraction gradually decreases, being replaced by sand in bottomlands (Ribeiro et al. 1999). Vegetation is characterized as lowland tropical rainforest, with fairly closed canopy and shady understory, characterized by the abundance of palm trees (Ribeiro et al. 1999; Costa et al. 2008).

Sampling design. Collection was conducted on a $5 \times 5 \mathrm{~km}$ grid composed of two perpendicular sets of $5 \mathrm{~km}$ long trails meeting every $1,000 \mathrm{~m}$. We collected on twelve trails, six running east-west and six north-south, totaling $60 \mathrm{~km}$ (Magnusson et al. 2005; Baccaro et al. 2008).

Wasp collection. Wasps were collected with an entomological net in the understory. Collection consisted in the visual search for colonies and flying individuals along the 60 segments $1,000 \mathrm{~m}$-long of the grid. While a collector walked the middle of a trail, two others walked along the sides, visually scanning the nearest $5 \mathrm{~m}$. One of the collectors was native to the region, skilled at locating objects inside the forest. Generally, searches occurred from 8 am to $4 \mathrm{pm}$, totaling about 130 sampling hours (approximately 2 hours per trail) during eight days in August and eight days in October 2010. All wasps and colonies collected were georeferenced using a Global Positioning System. The environment where each individual or colony was collected was classified as plateau/ slope in continuous forest, clearing, or bottomland close to a "igarapé" (local name for creeks and streams).

Collected specimens and nests were deposited in the Invertebrate Collection of the National Research Institute of Amazonia (Instituto Nacional de Pesquisas da Amazônia,
INPA). Species were identified with reference to the keys in Richards (1978) and Carpenter \& Marques (2001) and compared with specimens deposited at the INPA's Invertebrate Collection and Museu Paraense Emílio Goeldi.

Data analysis. For data analysis, trails were numbered 1 to 60 , according to layout, 1 to 30 being those running from east to west, and 31 to 60 from north to south. Relative abundance was estimated indirectly from species frequency in the samples (number of samples in which the species was recorded/total number of samples) (Silveira 2002), a record meaning any encounter with the species, individual or colony, and colony meaning simply an encounter.

All analyses were performed with the $\mathrm{R}$ program, version 2.13 (R Development Core Team 2011), Vegan package (Oksanen et al. 2008). To evaluate the process of species addition in response to increasing collecting effort, a species accumulation curve was constructed taking into consideration the presence/absence of each species in all the 60 trails $1,000 \mathrm{~m}$-long of the grid. Estimates of the asymptotic maximum number of species for the study area were also obtained using the Jackknife 1, Chao 1, and Bootstrap 1 estimators, in the same software. For the comparison of the collected data in all 1,000 m trails, ecological indices were used, such as Shannon-Wiener's diversity index ( $\left.\mathrm{H}^{\prime}\right)$, which attributes a greater weight to rare species and is relatively independent of sample size, and Pielou's homogeneity index (J), which refers to the distribution patterns of individuals among species, one of the components of diversity.

\section{RESULTS}

We identified 58 social wasp species, in 13 genera (Table I). Sixty-seven percent of the collected species belong to three genera: Polybia Lepeletier (21 species), Agelaia Ducke (ten species), and Mischocyttarus de Saussure (eight species). Aside from these, Polistes Latreille and Angiopolybia Araujo, had four and three species, respectively. The other genera were represented by two or one species only. One species each of Agelaia, Mischocyttarus (Clypeopolybia), and Polybia (Myrapetra) could not be determined to species level.

According to the Jackknife 1, Chao 1, and Bootstrap 1 estimators, the number of species of Vespidae for the Ducke Reserve grid can reach 60 . In the species accumulation curve, the number of species almost reaches the asymptote for 60 trails walked, and only a few species are added from the 30th trail onwards (Fig. 1).

In active search routes, 708 specimens were recorded and collected, mostly in flight $(97.8 \%)$. The most frequent species in active search paths were Agelaia fulvofasciata, Agelaia testacea and Angiopolybia pallens (Table I), totaling 58\% of the findings. Few species occurred in samples in a frequency greater than $20 \%$, while the majority ( 47 species) were often below $10 \%$. Thirty-eight species were represented by one or two individuals, mainly of the genera Polybia (14), Mischocyttarus (6), and Polistes (4). Within the genus Polybia, comprising 21 species in the study area, only Polybia rejecta, 
Table I. Social wasp species collected on a $25 \mathrm{~km}^{2}$ grid at the Ducke Reserve, Amazonas, Brazil. Number of records, frequency (number of samples in which the species was recorded divided by the total number of samples), and environment type where each species was collected in the 60 trails of the study grid. PS: Plateau/Slope; BS: Bottomland/Stream; CL: Clearing.

\begin{tabular}{|c|c|c|c|}
\hline Taxon & Number of records & Frequency \% & Environment type \\
\hline \multicolumn{4}{|l|}{ Epiponini } \\
\hline Agelaia angulata (Fabricius, 1804) & 16 & 21.6 & PS, BS \\
\hline Agelaia cajennensis (Fabricius, 1798) & 4 & 6.7 & PS, BS \\
\hline Agelaia centralis (Cameron, 1907) & 25 & 21.6 & $\mathrm{PS}, \mathrm{CL}$ \\
\hline Agelaia constructor (de Saussure, 1854) & 13 & 18.3 & PS, BS \\
\hline Agelaia fulvofasciata (DeGeer, 1773) & 249 & 88.3 & PS, BS, CL \\
\hline Agelaia myrmecophila (Ducke, 1905) & 4 & 6.7 & PS, BS \\
\hline Agelaia ornata (Ducke, 1905) & 1 & 1.7 & PS \\
\hline Agelaia pallipes (Olivier, 1791) & 53 & 36.7 & PS, BS, CL \\
\hline Agelaia testacea (Fabricius, 1804) & 109 & 70.0 & PS, BS, CL \\
\hline Agelaia sp.1 & 2 & 3.3 & PS \\
\hline Angiopolybia obidensis (Ducke, 1904) & 23 & 33.3 & PS, BS, CL \\
\hline Angiopolybia pallens (Lepeletier, 1836) & 77 & 46.7 & PS, BS, CL \\
\hline Angiopolybia paraensis (Spinola, 1851) & 2 & 3.3 & PS \\
\hline Apoica arborea de Saussure, 1854 & 1 & 1.7 & PS \\
\hline Apoica pallens (Fabricius, 1804) & 1 & 1.7 & PS \\
\hline Chartergellus amazonicus Richards, 1978 & 1 & 1.7 & $\mathrm{CL}$ \\
\hline Charterginus fulvus Fox, 1898 & 1 & 1.7 & BS \\
\hline Clypearia apicipennis (Spinola, 1851) & 1 & 1.7 & PS \\
\hline Clypearia sulcata (de Saussure, 1854) & 1 & 1.7 & BS \\
\hline Epipona tatua (Cuvier, 1797) & 1 & 1.7 & PS \\
\hline Leipomeles dorsata (Fabricius, 1804) & 1 & 1.7 & $\mathrm{CL}$ \\
\hline Polybia belemensis Richards, 1970 & 1 & 1.7 & PS \\
\hline Polybia bicyttarella Richards, 1951 & 1 & 1.7 & $\mathrm{CL}$ \\
\hline Polybia bistriata (Fabricius, 1804) & 4 & 6.7 & PS, BS \\
\hline Polybia depressa (Ducke, 1905) & 1 & 1.7 & PS \\
\hline Polybia dimidiata (Olivier, 1791) & 4 & 6.7 & PS, BS \\
\hline Polybia dimorpha Richards, 1978 & 3 & 5.0 & PS, BS \\
\hline Polybia dubitata Ducke, 1910 & 1 & 1.7 & PS \\
\hline Polybia fastidiosuscula de Saussure, 1854 & 1 & 1.7 & PS \\
\hline Polybia jurinei de Saussure, 1854 & 2 & 1.7 & PS \\
\hline Polybia liliacea (Fabricius, 1804) & 9 & 15.0 & PS, BS, CL \\
\hline Polybia occidentalis (Olivier, 1791) & 3 & 5.0 & PS, BS, CL \\
\hline Polybia parvulina Richards, 1970 & 1 & 1.7 & PS \\
\hline Polybia platycephala Richards, 1951 & 1 & 1.7 & BS \\
\hline Polybia quadricincta de Saussure, 1854 & 2 & 3.3 & PS \\
\hline Polybia rejecta (Fabricius, 1798) & 33 & 36.7 & PS, BS, CL \\
\hline Polybia rufitarsis Ducke, 1904 & 1 & 1.7 & PS \\
\hline Polybia scrobalis Richards, 1970 & 2 & 3.3 & PS \\
\hline Polybia sericea (Olivier, 1791) & 10 & 16.7 & PS, BS, CL \\
\hline Polybia singularis Ducke, 1905 & 1 & 1.7 & PS \\
\hline Polybia velutina Ducke, 1905 & 2 & 3.3 & PS \\
\hline Polybia (Myrapetra) sp.1 & 1 & 1.7 & BS \\
\hline Protopolybia bituberculata Silveira \& Carpenter, 1995 & 1 & 1.7 & PS \\
\hline Protopolybia chartergoides (Gribodo, 1891) & 1 & 1.7 & PS \\
\hline Synoeca surinama (Linnaeus, 1767) & 15 & 25.0 & PS, BS, CL \\
\hline Synoeca virginea (Fabricius, 1804) & 2 & 1.7 & PS, BS \\
\hline \multicolumn{4}{|l|}{ Mischocyttarini } \\
\hline Mischocyttarus (Clypeopolybia) flavicans (Fabricius, 1804) & 3 & 5.0 & $\mathrm{CL}$ \\
\hline Mischocyttarus (Clypeopolybia) sp.1 heliconius group & 1 & 1.7 & $\mathrm{CL}$ \\
\hline Mischocyttarus (Haplometrobius) surinamensis (de Saussure, 1854) & 1 & 1.7 & PS \\
\hline Mischocyttarus (Kappa) socialis (de Saussure, 1854) & 1 & 1.7 & PS \\
\hline Mischocyttarus (Megacanthopus) collaris (Ducke, 1904) & 1 & 1.7 & PS \\
\hline Mischocytarus (Mischocytarus) labiatus (Fabricius, 1804) & 5 & 8.3 & $\mathrm{PS}, \mathrm{CL}$ \\
\hline Mischocyttarus (Mischocyttarus) rotundicollis (Cameron, 1912) & 1 & 1.7 & PS \\
\hline Mischocytarus (Monogynoecus) lecointei (Ducke, 1904) & 1 & 1.7 & PS \\
\hline \multicolumn{4}{|l|}{ Polistini } \\
\hline Polistes canadensis (Linnaeus, 1758) & 2 & 3.3 & PS \\
\hline Polistes goeldi Ducke, 1904 & 1 & 1.7 & PS \\
\hline Polistes pacificus Fabricius, 1804 & 1 & 1.7 & $\mathrm{CL}$ \\
\hline Polistes testaceicolor Bequaert, 1798 & 1 & 1.7 & PS \\
\hline Total records & 708 & & \\
\hline Total species & 58 & & \\
\hline
\end{tabular}




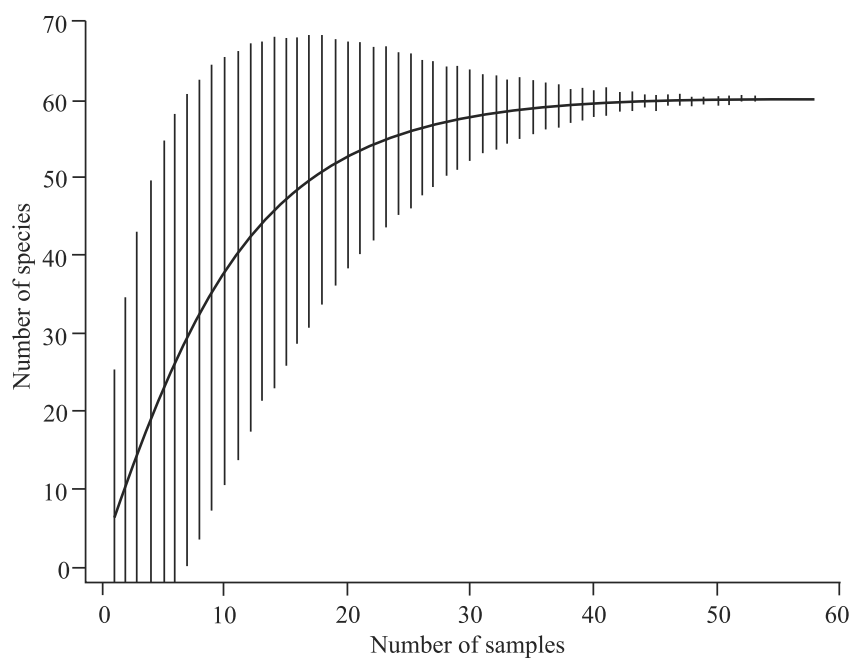

Fig. 1. Species accumulation curve for social wasps in trails of the PPBio grid at the Ducke Reserve, Amazonas, Brazil.

Polybia sericea, and Polybia liliacea were recorded with frequencies greater than $10 \%$. The most frequent species of Mischocyttarus was Mischocyttarus labiatus, with five individuals.

Location of colonies was a rare event when compared to capture of individuals with entomological net. Eighteen colonies of social wasps, belonging to 12 species, were found: Agelaia constructor (1), Agelaia pallipes (1), Angiopolybia pallens (1), Mischocyttarus collaris (1), Polybia bistriata (1), Polybia dubitata (1), Polybia jurinei (1), Polybia liliacea (1), Polybia occidentalis (2), Polybia rejecta (1), Protopolybia bituberculata (1), Synoeca virginea (1), and five uninhabited nests of Mischocyttarus (1), Polybia (3), and Polistes (1) which could not be determined to species level.

Most colonies (10) were found on the abaxial side of leaves, especially palms (Arecaceae), and a species of Marantaceae close to streams; those of Polybia bistriata, Polybia dubitata, Polybia occidentalis, Protopolybia bituberculata, and Mischocyttarus collaris were found on this substrate. Colonies of Angiopolybia pallens, Polybia jurinei, Polybia liliacea, and Polybia rejecta were hanging from branches. The nest of Synoeca virginea was wrapped around a thin branch, while that of Agelaia pallipes was inside a tree trunk, and that of Agelaia constructor was inside a burrow excavated in the soil.

The richness on trails varied from two to ten species. Few diversity values exceeded 1.9 , which is considered high in this study (Table II). However, homogeneity was high on most trails, showing a better species distribution along them; on trail 11, all individuals collected belonged to different species.

The 708 individuals and colonies collected were obtained at 425 collection points on the grid. Species were unevenly distributed in the three distinct environments where collection was conducted. Plateau/slope areas had the highest number of species, followed by bottomlands with streams and by clearings (Table III).

\section{DISCUSSION}

The social wasp fauna of the Ducke Reserve known until now consists of 65 species of Polistinae, collected by several researchers and deposited at INPA's Invertebrate Collection. The collections performed at the PPBio grid added 26 species, raising to 86 the number of known species. Nevertheless, taxonomic composition varied regarding the material at the INPA's collection, since 31 species previously collected in Ducke Reserve were not found in the study grid, mainly due to the active search method employed. Some wasps of genera Brachygastra, Metapolybia, Parachartergus and Pseudopolybia were only collected using Malaise traps and suspended Malaise traps, according to the INPA Collection.

The number of species obtained is high (58), and more so than that of other areas studied in Amazonia, except at the Caxiuanã National Forest PPBio grid. One reason for the greater richness obtained by Silva \& Silveira (2009) at Caxiuanã is related with field work duration, which was 44 days at Caxiuanã and 16 at Ducke. Another reason was the inclusion of ten Malaise traps randomly distributed on Caxiuanã trails, which we chose not to do at Ducke. Anyway, we suggest that the two PPBio grids (Ducke and Caxiuanã) are very similar with respect to number of species and even genera (58 and $65 ; 13$ and 12 , respectively).

There are different methods to sample social wasps; however, few studies have attempted to propose a standardization of these methods or to establish comparable and adequate protocols to survey the fauna of a given site. An important factor to consider in the implementation of novel social wasp sampling protocols is the distribution pattern of these organisms (Silveira 2002; Silva \& Silveira 2009) or, when using traps, finding the most efficient ones to collect the target group and dispose them in a standardized manner (Noll \& Gomes 2009).

This study corroborates the results of Silva \& Silveira (2009), who considered active search the most efficient method for collecting Vespidae, mainly close to the forest ground and in the understory. The use of three collectors, as performed by those authors, was also considered crucial to the development of the work, since searching trail center, ends, and edges allows more sightings. Therefore, we believe that the collection protocol adopted in this work and by Silva \& Silveira (2009) can be used in studies of social wasp diversity, especially when working on pre-established transects.

Moreover, the richness found ( 58 species) and estimated (60) are similar; thus, finding more species would require more detailed searches. In this area, probably, it would be very difficult to collect another wasp species in the understory. The best would be to use other methods, exploring other forest strata, such as the canopy (hanging Malaise trap) or attraction traps. This result suggests that the effort applied was sufficient to assess the Vespidae species composition in the study area.

Of the 58 species of social wasps found, some, like Agelaia fulvofasciata, Agelaia pallipes, Agelaia testacea, Angiopolybia 
Table II. Richness, Shannon-Wiener diversity $\left(\mathrm{H}^{\prime}\right)$, and Pielou Homogeneity $(\mathrm{J})$ of social wasp species measured in all 60 trails of the PPBio grid at the Ducke Reserve, Amazonas, Brazil. Trails were numbered from 1 to 60 according to spatial arrangement, 1 to 30 being oriented from east to west, and 31 to 60 from north to south.

\begin{tabular}{|c|c|c|c|c|c|c|c|}
\hline Trail & Richness & Diversity (H') & Homogeneity $(\mathrm{J})$ & Trail & Richness & Diversity (H') & Homogeneity $(\mathrm{J})$ \\
\hline 1 & 5 & 1.5500 & 0.9630 & 31 & 5 & 1.4790 & 0.9190 \\
\hline 2 & 4 & 0.9641 & 0.6954 & 32 & 4 & 0.4954 & 0.3573 \\
\hline 3 & 6 & 1.7200 & 0.9601 & 33 & 4 & 1.3300 & 0.9591 \\
\hline 4 & 6 & 1.5400 & 0.8593 & 34 & 6 & 1.7330 & 0.9671 \\
\hline 5 & 5 & 1.0760 & 0.6686 & 35 & 7 & 1.6150 & 0.8300 \\
\hline 6 & 4 & 0.8223 & 0.5931 & 36 & 4 & 0.9372 & 0.6760 \\
\hline 7 & 7 & 1.5890 & 0.8166 & 37 & 9 & 1.7290 & 0.7871 \\
\hline 8 & 6 & 1.6330 & 0.9112 & 38 & 5 & 1.6090 & 1.0000 \\
\hline 9 & 3 & 0.6837 & 0.6224 & 39 & 11 & 2.3050 & 0.9611 \\
\hline 10 & 5 & 1.2680 & 0.7877 & 40 & 4 & 1.2420 & 0.8962 \\
\hline 11 & 8 & 1.8240 & 0.8773 & 41 & 6 & 1.6770 & 0.9359 \\
\hline 12 & 8 & 1.8400 & 0.8850 & 42 & 7 & 1.7780 & 0.9138 \\
\hline 13 & 4 & 1.1160 & 0.8053 & 43 & 5 & 1.5610 & 0.9697 \\
\hline 14 & 6 & 1.4400 & 0.8038 & 44 & 6 & 1.4110 & 0.7872 \\
\hline 15 & 4 & 1.3320 & 0.9610 & 45 & 8 & 1.8080 & 0.8695 \\
\hline 16 & 5 & 1.3030 & 0.8097 & 46 & 5 & 1.2630 & 0.7850 \\
\hline 17 & 5 & 1.6090 & 1.0000 & 47 & 2 & 0.6931 & 1.0000 \\
\hline 18 & 4 & 1.2770 & 0.9212 & 48 & 7 & 1.8310 & 0.9410 \\
\hline 19 & 4 & 1.3860 & 1.0000 & 49 & 4 & 1.3320 & 0.9610 \\
\hline 20 & 4 & 1.3860 & 1.0000 & 50 & 3 & 0.8815 & 0.8024 \\
\hline 21 & 8 & 1.9720 & 0.9485 & 51 & 5 & 1.0940 & 0.6800 \\
\hline 22 & 7 & 1.8340 & 0.9427 & 52 & 10 & 2.2100 & 0.9599 \\
\hline 23 & 3 & 1.0400 & 0.9464 & 53 & 6 & 1.7920 & 1.0000 \\
\hline 24 & 8 & 1.9720 & 0.9485 & 54 & 3 & 1.0990 & 1.0000 \\
\hline 25 & 4 & 1.3860 & 1.0000 & 55 & 5 & 1.4650 & 0.9101 \\
\hline 26 & 7 & 1.6660 & 0.8563 & 56 & 4 & 0.7550 & 0.5446 \\
\hline 27 & 10 & 2.2050 & 0.9575 & 57 & 3 & 0.9503 & 0.8650 \\
\hline 28 & 8 & 1.7080 & 0.8212 & 58 & 4 & 1.3860 & 1.0000 \\
\hline 29 & 8 & 2.0200 & 0.9713 & 59 & 6 & 1.6670 & 0.9306 \\
\hline 30 & 3 & 1.0990 & 1.0000 & 60 & 5 & 1.6090 & 1.0000 \\
\hline
\end{tabular}

Table III. Number of collection points, individuals collected, and species of social wasps identified in the three different environment types where collection was conducted at the PPBio grid, Ducke Reserve, Amazonas, Brazil.

\begin{tabular}{lccc}
\hline & Plateau/Slope & Bottomland/Stream & Clearing \\
\hline Collection points (\%) & 86.6 & 8.5 & 4.9 \\
Individuals (\%) & 69.8 & 20.2 & 10 \\
Number of species & 48 & 22 & 18 \\
\hline
\end{tabular}

pallens, and Polybia rejecta, are considered common in Amazonian environments (Silveira 2002; Silveira et al. 2005; Silva \& Silveira 2009). Others, like Chartergellus amazonicus, Clypearia apicipennis and Epipona tatua, were rare and probably have restricted distribution, as they are rarely collected in inventories (Silveira 2002).

In relation to frequency, Agelaia fulvofasciata repeated the pattern of being recorded more frequently, as in Caxiuanã (Silva \& Silveira 2009). This species was collected in almost $90 \%$ of the samples, in all environment types of the Ducke Reserve grid. The fact that it builds big colonies, well protected in cavities, may be the reason for its success in the Amazonian rainforest. Moreover, this species seems to prefer clearings, because a significant number of individuals were found in this environment, possibly due to higher solar incidence and warmth. Angiopolybia pallens was also very common, a result also found by Silveira (2002) at Caxiuanã. In this study, it was collected in $50 \%$ of the samples, especially near streams, suggesting a preference for humid and shaded situations. The latter two species are certainly the most collected and common in Amazonian rainforests (Silveira 2002). Agelaia testacea also occurred frequently (in about $70 \%$ of the samples); it is common in many environments in Amazonia, and its large size (about $25 \mathrm{~mm}$ ) facilitates its location and collection.

Species not frequent in the grid, such as Polybia rejecta and Polybia sericea, were most often recorded in clearings and were rarely captured in close forest or near streams. Furthermore, the only Polybia rejecta colony was also found in an open area. On the contrary, most records of Agelaia angulata, Angiopolybia obidensis, and Synoeca surinama were obtained in closed forest, with abundance of palms. Agelaia pallipes and Agelaia centralis were collected in all kinds of environment, and were similarly distributed in different areas along the grid. Mischocyttarus labiatus and Polistes canadensis occurred only in clearings and southernmost trails, closer to Manaus urban area.

At the Ducke Reserve, most individuals and colonies occurred in the northern part of the grid, more preserved and composed predominantly by closed forest. In the south, closer 
to Manaus, where there are more streams, inundated lands, and clearings, according to visual evaluation of the collectors, there were few individuals but more species. Trails with streams and clearings are more species-rich than those crossing only plateaus and slopes. The most diverse areas, where trails cross plateaus/slopes, bottomlands/streams, and clearings, are in the southern part of the grid, and are probably the most heterogeneous environmentally, which may explain this result.

Social wasps are highly territorial insects, with populations showing considerable species concentration in the same location, and the clustered aggregation pattern predominates (Richards 1971). Taking these factors into account, it is possible that conducting an inventory in a limited area, even if reasonably large, like the PPBio grid, yield a subset of the local fauna only. On the other hand, the systematic sampling of an area imposed by a regular grid layout may minimize these shortcomings, and a more concentrated effort could offset the effect of the decreased total area to be explored.

The number of colonies found (18) is well below than the 74 colonies found at Caxiuanã, Pará (Silva \& Silveira 2009). The lower richness and abundance of colonies in denser forest may be related to the difficulty of detecting them in these environments and also in the upper forest stratum, where they are very cryptic (Wenzel \& Carpenter 1994; Tanaka-Jr. \& Noll 2011). Another factor is that all samples were collected in the dry season (August to October), and this may not be the preferred nesting period of social wasps, considering this low number. Despite the difficulties of collecting in Amazonian environments due to canopy height, the higher richness found at the Ducke Reserve when compared to other biomes can be explained by the higher structural complexity of these environments, composed by dense forest, clearings, bottomlands, streams, slopes and plateaus, that allows the establishment and survival of more species of social wasps, providing microhabitats for the organisms, greater protection from predators, and increased availability and diversity of food resources and nesting substrates (Lawton 1983; Santos et al. 2007). Vegetation exerts direct influence on social wasp communities, providing support for nesting and food resources, indirectly affecting those communities by variations in temperature, humidity, and amount of shade in the environment (Wenzel 1991; Diniz \& Kitayama 1994; Dejean et al. 1998).

The grid installed at the Ducke Reserve provided, for the first time, a structured inventory of the social wasps of a biological reserve in Central Amazonia at a significant sampling scale. The results show that the Ducke Reserve harbors a forest that maintains a medium to high species richness of social wasps, similar to other "terra firme" areas in Amazonia.

\section{ACKNOWLEDGMENTS}

We sincerely thank Fernando B. Noll, Elisabeth Franklin and Jorge P. Souza for their valuable suggestions on the manuscript; Marcos Torres, Valdeana Linard, Lucas Marques de Camargos, Vítor Dias Tarli and Paulo da Silva Lopes for help in the field; to Conselho Nacional de Desenvolvimento Científico e Tecnológico (CNPq), Fundação de Amparo à Pesquisa do Estado do Amazonas (FAPEAM) and Biodiversity Research Program (PPBio) for support, to Coordenação de Aperfeiçoamento de Pessoal de Nivel Superior (Capes) for the scholarship to the first autor; and Pedro Santos for help with the English version.

\section{REFERENCES}

Almeida, S.M., Andena, S.R. \& Anjos-Silva, E.J. 2014. Diversity of the nests of social wasps (Hymenoptera: Vespidae: Polistinae) in the northern Pantanal, Brazil. Sociobiology 61: 107-114.

Auad, A.M., Carvalho, C.A., Clemente, M. \& Prezoto, F. 2010. Diversity of Social Wasps in a Silvipastoral System (Hymenoptera). Sociobiology 55: 627-636.

Baccaro, F.B., Drucker, D.P., Vale, J. do, Oliveira, M.L. de, Magalhães, C., Lepsch-Cunha, N. \& Magnusson, W.E. 2008. A Reserva Ducke, p. 11-20. In: Oliveira, M.L. de, Baccaro, F.B., Braga-Neto, R. \& Magnusson, W.E. (Eds.). Reserva Ducke, a biodiversidade amazônica através de uma grade. Manaus, Instituto Nacional de Pesquisas da Amazônia, Áttema Design Editorial 166 p.

Carpenter, J.M. 2004. Synonymy of the genus Marimbonda Richards, 1978, with Leipomeles Möbius, 1856 (Hymenoptera: Vespidae: Polistinae), and a new key to the genera of paper wasps of the New World. American Museum Novitates 3456: 1-16.

Carpenter, J.M. \& Marques, O.M. 2001. Contribuição ao Estudo dos Vespídeos do Brasil. (Insecta, Hymenoptera, Vespoidea, Vespidae). Cruz das Almas, Universidade Federal da Bahia, Departamento de Fitotecnia. Série Publicações Digitais, v. 3, CD-ROM, 147 p.

Costa, F., Castilho, C., Drucker, D.P., Kinupp, V., Nogueira, A. \& Spironello, W. 2008. Flora, p. 21-30. In: Oliveira, M.L. de, Baccaro, F.B., BragaNeto, R. \& Magnusson, W.E. (Eds.). Reserva Ducke, a biodiversidade amazônica através de uma grade. Manaus, Instituto Nacional de Pesquisas da Amazônia, Áttema Design Editorial Ltda., 166 p.

Dejean, A., Corbara, B. \& Carpenter, J.M. 1998. Nesting site selection by wasps in the Guianese rain forest. Insectes Sociaux 45: 33-41.

Diniz, I.R. \& Kitayama, K. 1994. Colony densities and preferences for nest habitat of some social wasps in Mato Grosso State, Brazil (Hymenoptera: Vespidae). Journal of Hymenoptera Research 3: 133-143.

Gomes, B. \& Noll, F.B. 2009. Diversity of social wasps (Hymenoptera, Vespidae, Polistinae) in three fragments of semideciduous seasonal forest in the northwest of São Paulo State, Brazil. Revista Brasileira de Entomologia 53: 428-431.

Grandinete, Y.C. \& Noll, F.B. 2013. Checklist of social (Polistinae) and solitary (Eumeninae) wasps from a fragment of Cerrado "campo sujo" in the state of Mato Grosso do Sul. Sociobiology 60: 101-106.

Lawton, J.H. 1983. Plant architecture and the diversity of phytophagous insects. Annual Review of Entomology 28: 23-39.

Lima, M.A.P., Lima, J.R. \& Prezoto, F. 2000. Levantamento dos gêneros de vespas sociais (Hymenoptera, Vespidae), flutuação das colônias e hábitos de nidificação no campus da UFJF, Juiz de Fora, MG. Revista Brasileira de Zoociências 2: 69-80.

Lima, A.C.O., Castilho-Noll, M.S.M., Gomes, B. \& Noll, F.B. 2010. Social wasp diversity (Vespidae, Polistinae) in a forest fragment in the northeast of São Paulo State sampled with different methodologies. Sociobiology 55: 613-626.

Locher, G.A., Togni, O.C., Silveira, O.T. \& Giannotti, E. 2014. The social wasp fauna of a riparian forest in southeastern Brazil (Hymenoptera, Vespidae). Sociobiology 61: 225-233

Magnusson, W.E., Lima, A.P., Luizão, R., Costa, F.R.C., Castilho, C.V. de \& Kinupp, V.F. 2005. RAPELD: a modification of the Gentry method for biodiversity surveys in long-term ecological research sites. Biota Neotropica 5: 1-6. 
Marques Filho, A.O., Ribeiro, M.N.G., Santos, H.M. \& Santos, J.M. 1981. Estudos climatológicos da Reserva Florestal Ducke, Manaus-AM. IV. Precipitação. Acta Amazonica 11: 759-768.

Morato, E.F., Amarante, S.T. \& Silveira, O.T. 2008. Avaliação ecológica rápida da fauna de vespas (Hymenoptera: Aculeata) do Parque Nacional da Serra do Divisor, Acre, Brasil. Acta Amazonica 38: 789-798.

Noll, F.B. \& Gomes, B. 2009. An improved bait method for collecting Hymenoptera, especially social wasps (Vespidae: Polistinae). Neotropical Entomology 38: 477-481.

Oksanen, J., Kindt, R., Legendre, P., O'Hara, B., Simpson, G.L., Solymos, P., Henry, M., Stevens, H.H. \& Wagner, H. 2008. Vegan: Community Ecology Package. R package version 1. 13 p.

Pires, J.M. 1974. Tipos de vegetação da Amazônia. Brasil Florestal 5: 48-58.

Prezoto, F. \& Clemente, M.A. 2010. Vespas sociais do Parque Estadual do Ibitipoca, Minas Gerais, Brasil. MG.Biota 3: 22-32.

R Development Core Team. 2011. R: A Language and Environment for Statistical Computing. Vienna, Austria: the R Foundation for Statistical Computing. Available at: http://www.R-project.org/.

Raw, A. 1998. Social Wasps (Hymenoptera: Vespidae) of the Ilha de Maracá, p. 307-321. In: Ratter, J.A. \& Milliken, W. (eds.). Maracá. Biodiversity and environment of an Amazonian Rainforest. Chichester, John \& Sons, 508 p.

Ribeiro, M.N.G. \& Adis, J. 1984. Local rainfall variability - a potential bias for bioecological studies in the Central Amazon. Acta Amazonica 14: $159-174$

Ribeiro, J.E.L.S., Hopkins, M.J.G., Vicentini, A., Sothers, C.A., Costa, M.A.S., Brito, J.M., Souza, M.A.D., Martins, L.H.P., Lohmann, L.G., Assunção, P.A.C.L., Pereira, E.C., Silva, C.F., Mesquita, M.R. \& Procópio, L.C. 1999. Flora da Reserva Ducke: Guia de identificação das plantas vasculares de uma floresta de terra-firme na Amazônia Central. Manaus, Instituto Nacional de Pesquisas da Amazônia, $799 \mathrm{p}$.

Richards, O.W. 1971. The biology of the social wasps (Hymenoptera: Vespidae). Biological Reviews 46: 483-528.

Richards, O.W. 1978. The social wasps of the Americas (excluding the Vespinae). London, British Museum Press, vii+580 p.

Santos, G.M.M., Bichara-Filho, C.C., Resende, J.J. Cruz, J.D. \& Marques, O.M. 2007. Diversity and community structure of social wasps
(Hymenoptera: Vespidae) in three ecosystems in Itaparica Island, Bahia State, Brazil. Neotropical Entomology 36: 180-185.

Silva, S.S. \& Silveira, O.T. 2009. Vespas sociais (Hymenoptera, Vespidae, Polistinae) de floresta pluvial Amazônica de terra firme em Caxiuanã, Melgaço, Pará. Iheringia, Série Zoologia 99: 317-323.

Silva, S.S., Azevedo, G.G. \& Silveira, O.T. 2011. Social wasps of two Cerrado localities in the northeast of Maranhão state, Brazil (Hymenoptera, Vespidae, Polistinae). Revista Brasileira de Entomologia 55: 597-602.

Silva-Pereira, V. \& Santos, G.M.M. 2006. Diversity in bee (Hymenoptera: Apoidea) and social wasp (Hymenoptera: Vespidae, Polistinae) community in "Campos Rupestres", Bahia, Brazil. Neotropical Entomology 35: 165-174.

Silveira, O.T. 2002. Surveying Neotropical Social Wasps. An evaluation of methods in the "Ferreira Penna" Research Station (ECFPn), in Caxiuanã, PA, Brazil (Hym., Vespidae, Polistinae). Papéis Avulsos de Zoologia 42: 299-323.

Silveira, O.T., Esposito, M.C., Santos Jr., J.N. \& Gemaque Jr., F.E. 2005. Social wasps and bees captured in carrion traps in a rainforest in Brazil. Entomological Science 8: 33-39.

Silveira, O.T., Costa Neto, S.V. da \& Silveira, O.F.M. da 2008. Social wasps of two wetland ecosystems in Brazilian Amazonia (Hymenoptera, Vespidae, Polistinae). Acta Amazonica 38: 333-344.

Somavilla, A., Köhler, A. \& Hermes, M.G. 2010. Contribuição aos estudos dos Vespidae ocorrentes no estado do Rio Grande do Sul (Insecta, Hymenoptera). Revista Brasileira de Biociências 8: 257-263.

Tanaka-Jr., G.M. \& Noll, F.B. 2011. Diversity of social wasps on semideciduous seasonal forest fragments with different surrounding matrix in Brazil. Psyche 2011: 1-8.

Togni, O.C., Locher, G.A., Giannotti, E. \& Silveira, O.T. 2014. The social wasp community (Hymenoptera, Vespidae) in an area of Atlantic Forest, Ubatuba, Brazil. Check List 10: 10-17.

Wenzel, J.W. 1991. The evolution of nest architecture in the social vespids, p. 480-519. In: Ross, K.G. \& Matthews, R.W. (eds.). The social biology of wasps. Ithaca, Cornell University Press, 678 p.

Wenzel, J.W. \& Carpenter, J.M. 1994. Comparing methods, adaptative traits and tests of adaptation, p. 79-101. In: Eggleton, P. \& VaneWright, R. (eds.). Phylogenetics and ecology. London, Academic Press, 376 p.

Received 8 August 2014; accepted 6 October 2014

Associate Editor: Marcel G. Hermes 